\title{
Mechanism of the antioxidant to pro-oxidant switch in the behavior of dehydroascorbate during LDL oxidation by copper(II) ions
}

DOI:

10.1016/j.abb.2007.07.005

\section{Document Version \\ Accepted author manuscript}

Link to publication record in Manchester Research Explorer

Citation for published version (APA):

Horsley, E. T. M., Burkitt, M. J., Jones, C. M., Patterson, R. A., Harris, L. K., Moss, N. J., del Rio, J. D., \& Leake, D. S. (2007). Mechanism of the antioxidant to pro-oxidant switch in the behavior of dehydroascorbate during LDL oxidation by copper(II) ions. Archives of Biochemistry and Biophysics, 465(2), 303-314.

https://doi.org/10.1016/j.abb.2007.07.005

\section{Published in:}

Archives of Biochemistry and Biophysics

\section{Citing this paper}

Please note that where the full-text provided on Manchester Research Explorer is the Author Accepted Manuscript or Proof version this may differ from the final Published version. If citing, it is advised that you check and use the publisher's definitive version.

\section{General rights}

Copyright and moral rights for the publications made accessible in the Research Explorer are retained by the authors and/or other copyright owners and it is a condition of accessing publications that users recognise and abide by the legal requirements associated with these rights.

\section{Takedown policy}

If you believe that this document breaches copyright please refer to the University of Manchester's Takedown Procedures [http://man.ac.uk/04Y6Bo] or contact uml.scholarlycommunications@manchester.ac.uk providing relevant details, so we can investigate your claim.

\section{OPEN ACCESS}




\section{Mechanism of the antioxidant to pro-oxidant switch in the behavior of dehydroascorbate during LDL oxidation by copper(II) ions}

Elizabeth T. M. Horsley, ${ }^{*}$ Mark J. Burkitt, ${ }^{\dagger * *}$ Clare M. Jones, ${ }^{\dagger}$ Rebecca A. Patterson, ${ }^{\dagger \dagger}$ Lynda K. Harris ${ }^{\S}$ Nicola J. Moss, ${ }^{\S}$ Jessica D. del Rio and David S. Leake ${ }^{1}$

Cardiovascular Research Group, Biomolecular Sciences Section, School of Biological Sciences, University of Reading, Whiteknights, PO Box 228, Reading, Berkshire, RG6 6AJ, United Kingdom, and ${ }^{\dagger}$ Gray Cancer Institute, PO Box 100, Mount Vernon Hospital, Northwood, Middlesex, HA6 2JR, United Kingdom

Running title: Dehydroascorbic acid and LDL oxidation

${ }^{1}$ To whom correspondence should be addressed. e-mail: d.s.leake@ reading.ac.uk; Tel +44 118378 7062; Fax +441189310180

*Present address: Vertex Pharmaceuticals, Boston, MA, U.S.A.

***esent address: 3 Linnet Drive, Westcott, Aylesbury, Bucks, HP18 0PB

${ }^{\dagger}$ Present address: PRA International, Reading, United Kingdom

${ }^{\S}$ Present address: Academic Unit of Obstetrics and Gynaecology, University of Manchester, United Kingdom

${ }^{\S}$ Present address: Aventis Pharma Ltd, West Malling, Kent, United Kingdom Subject area: Systems biochemistry

Abbreviations: BCDS, bathocuproine disulphonic acid; DMPO, 5,5-dimethyl-1-pyrroline $N$-oxide; EPR, electron paramagnetic resonance; 13-HPODE, 13(S)-hydroperoxyoctadeca-9Z,11E-dienoic acid 


\section{ABSTRACT}

Oxidised low density lipoprotein (LDL) may be involved in the pathogenesis of atherosclerosis. We have therefore investigated the mechanisms underlying the antioxidant/pro-oxidant behavior of dehydroascorbate, the oxidation product of ascorbic acid, toward LDL incubated with $\mathrm{Cu}^{2+}$ ions. By monitoring lipid peroxidation through the formation of conjugated dienes and lipid hydroperoxides, we show that the pro-oxidant activity of dehydroascorbate is critically dependent on the presence of lipid hydroperoxides, which accumulate during the early stages of oxidation. Using electron paramagnetic resonance spectroscopy, we show that dehydroascorbate amplifies the generation of alkoxyl radicals during the interaction of copper ions with the model alkyl hydroperoxide, tert-butylhydroperoxide. Under continuous-flow conditions, a prominent doublet signal was detected, which we attribute to both the erythroascorbate and ascorbate free radicals. On this basis, we propose that the pro-oxidant activity of dehydroascorbate toward LDL is due to its known spontaneous interconversion to erythroascorbate and ascorbate, which reduce $\mathrm{Cu}^{2+}$ to $\mathrm{Cu}^{+}$and thereby promote the decomposition of lipid hydroperoxides. Various mechanisms, including copper chelation and $\mathrm{Cu}^{+}$oxidation, are suggested to underlie the antioxidant behavior of dehydroascorbate in LDL that is essentially free of lipid hydroperoxides.

Key words: ascorbic acid; atherosclerosis; copper; dehydroascorbate; EPR spectroscopy; lipid hydroperoxide; lipid peroxidation; lipoprotein; low density lipoprotein; low density lipoprotein oxidation. 


\section{INTRODUCTION}

The oxidative modification of low density lipoprotein (LDL) is believed widely to be involved in the pathogenesis of human atherosclerosis [1], the underlying cause of coronary heart disease and most strokes. A number of large clinical trials have shown no decrease in cardiovascular disease after antioxidant supplementation, however, and the importance of oxidised LDL in atherosclerosis is therefore an unresolved issue [2]. Several studies have demonstrated that LDL can be oxidised in vitro by cells associated with atherosclerotic lesions [3-7]. The mechanisms of LDL oxidation in vivo are controversial [1]. Possibilities to explain how LDL is oxidised in atherosclerotic lesions include lipoxygenase, myeloperoxidase/nitrite, peroxynitrite, NADPH oxidase, xanthine oxidase, mitochondrial respiration, iron or copper [8]. LDL oxidation by cells in vitro appears to be dependent usually on the presence of iron or copper ions in a redox-active form, which are believed to catalyse the free-radical reactions responsible for LDL oxidation [3-5, 9-11]. Metal ions can also oxidise LDL directly when incubated in cell-free medium [3, 4, 9, 12]. Caeruloplasmin, which contains most of the plasma copper, has also been shown to oxidise LDL by cells in vitro [13-15], which depends on superoxide generated by these cells [15]. The presence in human atherosclerotic lesions of redox-active metal ions [16] and products indicative of freeradical attack upon proteins $[17,18]$ is consistent with oxidation catalyzed by metal ions. This is also supported by the findings of a study, employing techniques that minimise the release of metal ions from proteins, showing elevated levels of copper and nonhaem iron in lesions [19], although it is uncertain if these increases are merely the result of tissue damage due to inflammation or are actively involved in the disease process.

Due to the epidemiological evidence indicating an inverse relationship between dietary fruit and vegetable intake and the incidence of cardiovascular disease [20,21], numerous studies have been undertaken to show that micronutrients provided by such diets, including $\alpha$-tocopherol [22, 23], ascorbic acid [24-27] and various flavonoids [28-31], can protect LDL from oxidative 
modification [32]. Under certain circumstances, however, they have been shown to display prooxidant activity. Indeed, it has been suggested the $\alpha$-tocopheroxyl radical, generated by the oxidation of $\alpha$-tocopherol within LDL, is the species responsible for the initiation of lipid peroxidation in the particle $[22,33,34]$.

Although ascorbic acid can be effective in the protection of LDL from oxidation by $\mathrm{Cu}^{2+}$ ions, it was first noted over a decade ago that this antioxidant acts as a pro-oxidant in LDL that has already undergone partial oxidation $[25,35]$. Subsequent studies have revealed similar properties in other common antioxidants, including flavonoids [30], nonflavonoid phenols [36], cysteine [37, 38], and urate [39-41]. The effects of ascorbate are further complicated by the fact that dehydroascorbate, the product of its two-electron oxidation, can itself act as both a pro-oxidant and an antioxidant toward LDL [24, 26, 35, 42]. Indeed in one study it was concluded that ascorbate per se offers LDL no protection from copper-dependent oxidation [24]. Instead, it was proposed that the protection observed with ascorbate is due solely to its oxidation to dehydroascorbate and, perhaps, subsequent degradation to other products. As dehydroascorbate is extremely unstable in aqueous solution, undergoing facile delactonization to 2,3-diketo-L-gulonic acid, followed by transformation into a large number of products, which include ascorbic acid and erythroascorbic acid [43-46], it is possible that the effects of dehydroascorbate on LDL oxidation are indirect and are caused by its transformation products.

The concentrations of dehydroascorbate reported in normal human plasma vary greatly, with values of undetectable levels [47], $3 \mu \mathrm{M}$ [48], 2-5 $\mu \mathrm{M}$ [49], $6 \mu \mathrm{M}$ [50], $12 \mu \mathrm{M}$ [51] and $29 \mu \mathrm{M}$ [52] being reported. The concentrations of dehydroascorbate can sometimes increase in states of inflammation or oxidative stress, for instance, in wounded skin in guinea-pigs [53] or in the plasma of smokers [54]. The levels of ascorbate were about ten times greater in human atherosclerotic lesions than in the normal arterial intima and the percentage contribution of dehydroascorbate to total vitamin $\mathrm{C}$ was $22 \%$ and $11 \%$, repectively [55]. 
In the present study, we have investigated in detail the mechanisms by which dehydroascorbate can act as both an antioxidant and a pro-oxidant toward $\mathrm{Cu}^{2+}$-challenged $\mathrm{LDL}$. In particular, we have sought to identify the factors responsible for this switch in behavior. Our electron paramagnetic resonance (EPR) experiments show very clearly that dehydroascorbate solutions bring about the rapid reduction of $\mathrm{Cu}^{2+}$, which is suggested to be caused by reaction with erythroascorbate, formed spontaneously from dehydroascorbate. The decomposition of lipid hydroperoxides by the $\mathrm{Cu}^{+}$formed in this reaction, which we have investigated by EPR spectroscopy using the model compound tert-butyl hydroperoxide, is proposed to be responsible for the pro-oxidant activity of dehydroascorbate toward partially oxidised LDL. The possible mechanisms by which dehydroascorbate may inhibit the initiation of lipid peroxidation in native LDL by $\mathrm{Cu}^{2+}$ are also discussed.

\section{Materials and methods}

PBS (without calcium or magnesium) was from Gibco Life Technologies, Paisley, Scotland. Ascorbic acid, bathocuproine disulphonic acid (BCDS), $\mathrm{CuCl}_{2} \cdot 2 \mathrm{H}_{2} \mathrm{O}, \mathrm{CuSO}_{4} \cdot 5 \mathrm{H}_{2} \mathrm{O}$, dehydroascorbate $\left(\mathrm{M}_{\mathrm{r}} 174.1\right.$; stated by the supplier to be at least $80 \%$ pure), 5,5-dimethyl-1pyrroline $N$-oxide (DMPO), tert-butyl hydroperoxide ( $\left.{ }^{t} \mathrm{BuOOH}\right), \alpha$-tocopherol, and tris(hydroxymethyl)aminomethane (Tris) were purchased from Sigma-Aldrich, Poole, Dorset, UK. $\alpha$-Tocopheryl acetate was from ICN Biomedicals Inc, Aurora, OH, USA; and 13(S)hydroperoxyoctadeca-9Z,11E-dienoic acid (13-HPODE) was from Affiniti, Exeter, Devon, UK. Dehydroascorbate was dissolved immediately before use. The DMPO was purified by vacuum distillation (Kugelrohr) and stored at $-80^{\circ} \mathrm{C}$. 


\section{Isolation of LDL}

LDL (density 1.019-1.063 $\mathrm{g} / \mathrm{ml}$ ) was isolated from the pooled plasma of healthy volunteers by sequential density ultracentrifugation in $\mathrm{KBr}$ solutions at $4{ }^{\circ} \mathrm{C}$ in the presence of EDTA $(100 \mu \mathrm{M})$, as described previously [56]. The LDL was dialysed against $3 \times 4$ litres $140 \mathrm{mM} \mathrm{NaCl}, 8.1 \mathrm{mM}$ $\mathrm{Na}_{2} \mathrm{HPO}_{4}, 1.9 \mathrm{mM} \mathrm{NaH}{ }_{2} \mathrm{PO}_{4}, \mathrm{pH} 7.4$, containing $100 \mu \mathrm{M}$ EDTA, sterilised by membrane filtration and assayed for protein by a modified Lowry assay [57]. Separate LDL preparations were used to repeat the experiments.

\section{Preparation of lipid hydroperoxide-rich LDL}

LDL (150 $\mu \mathrm{g}$ protein $/ \mathrm{ml})$ was oxidised at $37^{\circ} \mathrm{C}$ by adding $\mathrm{CuSO}_{4}(5 \mu \mathrm{M}$ net above the calculated final EDTA concentration) in PBS, as described previously [58]. Briefly, the initial absorbance at $234 \mathrm{~nm}$ was read and further readings were taken every 15-20 min. The reaction was stopped by the addition of $1 \mathrm{mM}$ EDTA once the absorbance had peaked. The lipid hydroperoxide-rich LDL was then concentrated by ultracentrifugation at $1.2 \mathrm{~g} / \mathrm{ml}$ and dialysed against 11 of the above phosphate buffer containing $100 \mu \mathrm{M}$ EDTA. It was then filter-sterilized and assayed for protein [57].

\section{Measurement of conjugated dienes}

$\operatorname{LDL}\left(50 \mu \mathrm{g}\right.$ protein $/ \mathrm{ml}$ ) was incubated at $37^{\circ} \mathrm{C}$ in PBS (without calcium or magnesium) in quartz cuvettes ( $1 \mathrm{~cm}$ light path). Additions of $\mathrm{CuSO}_{4}(5 \mu \mathrm{M}$ above the final calculated concentration of EDTA carried over from the LDL preparation, which was about $1 \mu \mathrm{M}$ ) were made to initiate the oxidation of LDL, in the presence or absence of dehydroascorbate, as indicated. The absorbance at $234 \mathrm{~nm}$ was recorded using a Perkin-Elmer Lambda 2 split beam UV/visible spectrophotometer at regular intervals [59]. 


\section{Lipid hydroperoxide assay}

The tri-iodide method of El-Saadani et al. [60], modified slightly as described previously [56], was used to determine lipid hydroperoxides in oxidised LDL (100 $\mu \mathrm{g}$ protein/ml). This concentration of oxidised LDL was used, rather than $50 \mu \mathrm{g}$ protein $/ \mathrm{ml}$, because the lipid hydroperoxide assay is less sensitive than the conjugated diene assay.

\section{Determination of $\alpha$-tocopherol levels in stored LDL}

Triplicate samples (200 $\mu \mathrm{g}$ protein) of LDL, stored in $140 \mathrm{mM} \mathrm{NaCl}, 8.1 \mathrm{mM} \mathrm{Na} 2 \mathrm{HPO}_{4}, 1.9$ $\mathrm{mM} \mathrm{NaH} \mathrm{PO}_{4}, \mathrm{pH} 7.4$, containing $100 \mu \mathrm{M}$ EDTA at $4^{\circ} \mathrm{C}$ for 4 days, were taken daily and frozen. The samples were then thawed and made up to $100 \mu$ with PBS. The internal standard $\alpha$ tocopheryl acetate $(200 \mu \mathrm{l}$ of $25 \mu \mathrm{M}$ dissolved in acetonitrile containing $20 \mu \mathrm{M}$ butylated hydroxytoluene) was then added to each of the vials followed by $0.8 \mathrm{ml}$ ethanol, $1.6 \mathrm{ml}$ iso-octane and $1 \mathrm{ml}$ water. Each vial was vortex mixed and centrifuged at $1,500 \times g$ for $5 \mathrm{~min}$. The upper organic layer was then removed and placed in a glass vial and evaporated to dryness under a stream of nitrogen. The residue was dissolved in $110 \mu \mathrm{l}$ acetonitrile and $100 \mu \mathrm{l}$ injected into a HPLC for analysis. A Hypersil ODS $3 \times 100 \mathrm{~mm}$, particle size $5 \mu \mathrm{m}$, Chrompack column was used. The mobile phase consisted of acetonitrile:water:tetrahydrofuran (80:6:14, by vol) at a flow rate of $1 \mathrm{ml} / \mathrm{min}$. Absorbance at $280 \mathrm{~nm}$ was used to detect $\alpha$-tocopherol.

\section{Determination of copper binding to LDL}

Copper binding to LDL was determined by equilibrium dialysis for $18 \mathrm{~h}$ in $3-(N-$ morpholino)propanesulphonic acid buffer, $\mathrm{pH} 7.4$, containing $10 \mu \mathrm{M} \mathrm{CuSO}_{4}$, as described previously [61]. 


\section{EPR spin-trapping studies}

The basic reaction mixture contained $0.1 \mathrm{M}$ DMPO, $10 \mathrm{mM}{ }^{t} \mathrm{BuOOH}$ and $1 \mathrm{mM} \mathrm{CuCl}_{2}$ in 0.1 M Tris- $\mathrm{HCl}$, pH 7.4. Where indicated, $5 \mathrm{mM}$ ascorbate or $5 \mathrm{mM}$ dehydroascorbate was included, and particular reactants were omitted. After thorough mixing, reactions were transferred to a quartz flat-cell and spectra (X-band) recorded using a Bruker EMX spectrometer (Bruker UK Ltd, Coventry, UK) equipped with a cylindrical cavity (HS model) and operating with the following instrument settings: modulation frequency, $100 \mathrm{kHz}$; sweep width, $80 \mathrm{G}$; microwave power, 20 $\mathrm{mW}$; modulation amplitude $0.5 \mathrm{G}$; sweep time $42 \mathrm{~s}$; time constant, $10.24 \mathrm{~ms}$; receiver gain, $2 \times$ $10^{5}$. Four spectra were accumulated and added.

\section{Continuous-flow EPR studies}

To observe directly the radicals generated during the mixing of $\mathrm{Cu}^{2+}$ with dehydroascorbate (or its degradation products), solutions containing $5 \mathrm{mM} \mathrm{CuCl}_{2}$ and $50 \mathrm{mM}$ dehydroascorbate (both in $0.1 \mathrm{M}$ Tris-HCl, $\mathrm{pH}$ 7.4) were flowed continuously through a dielectric mixing-resonator (model ER 4117 D-MVT, Bruker UK Ltd) housed in a Bruker EMX spectrometer, operating at the following instrument settings: modulation frequency, $100 \mathrm{kHz}$; sweep width, $150 \mathrm{G}$; microwave power, $20 \mathrm{~mW}$; modulation amplitude, $1 \mathrm{G}$; sweep time, $10.5 \mathrm{~s}$; time constant, $41 \mathrm{~ms}$; and receiver gain, $4 \times 10^{5}$. Where indicated, additional experiments were performed using ascorbate in place of dehydroascorbate. Flow through the cavity was maintained using a two-stream syringe infusion pump (model 22, Harvard Apparatus Ltd, Edenbridge, Kent, UK). The combined flow-rate was varied to achieve the range of mixing (reaction) times shown in Fig. 7. The calibration of this system (i.e., conversion of pump speeds to reaction times) has been described previously [62]. Complementary studies were also performed using ascorbate in place of dehydroascorbate. 


\section{Copper reduction assay}

The reduction of $\mathrm{Cu}^{2+}$ was assayed using BCDS, an indicator molecule whose absorbance at $480 \mathrm{~nm}$ increases with $\mathrm{Cu}^{+}$but not with $\mathrm{Cu}^{2+}$ [63]. The reaction was started by adding $\mathrm{CuSO}_{4}(5$ $\mu \mathrm{M})$ to cuvettes containing PBS and increasing concentrations of dehydroascorbate. Ascorbate was also added to one cuvette to reduce rapidly $\mathrm{Cu}^{2+}$ to $\mathrm{Cu}^{+}$and act as a standard. BCDS (360 $\mu \mathrm{M})$ was added immediately to the cuvettes and the formation of the (BCDS $)_{2} \mathrm{Cu}^{+}$complex followed at $480 \mathrm{~nm}$.

\section{Statistics}

One-way ANOVA was used to test for the significance of differences observed between various incubation conditions, as indicated.

\section{RESULTS}

\section{Dehydroascorbate protects native LDL from oxidation by $\mathrm{Cu}^{2+}$, but promotes the oxidation of partially oxidised LDL}

The incubation of native human $\mathrm{LDL}\left(50 \mu \mathrm{g}\right.$ protein/ml) with $5 \mu \mathrm{M} \mathrm{CuSO}_{4}$ resulted in oxidation of the constituent polyunsaturated fatty acids, as indicated by the formation of conjugated dienes (Fig. 1A). Consistent with previous studies [59, 64], the oxidation profile was characterized by an initial lag phase followed by a propagation phase, where the rate of conjugated diene formation was maximal, and then a decomposition phase. The addition of dehydroascorbate at concentrations of 10,20 , or $100 \mu \mathrm{M}$, before the addition of $\mathrm{Cu}^{2+}$ (i.e., at time zero), completely inhibited the formation of conjugated dienes for the duration of the experiment (Fig. 1A). In other experiments, dehydroascorbate did not inhibit the oxidation of LDL at a concentration of $0.1 \mu \mathrm{M}$, it sometimes inhibited at $1 \mu \mathrm{M}$ and it increased the lag phase by about 5-9 times at $3 \mu \mathrm{M}$. There was little effect on the rate of the propagation phase (data not shown). To investigate the 
possibility that dehydroascorbate protects LDL from oxidation by decreasing copper binding to the particle, an equilibrium dialysis technique was used. Consistent with previous studies, native LDL was found to bind $42.7 \pm 3.1$ copper ions per particle [61]. This was decreased to $28.6 \pm 1.4$, $22.2 \pm 0.9$, and $18.1 \pm 0.7$ copper ions in the presence of 10,25 , and $50 \mu \mathrm{M}$ dehydroascorbate, respectively (mean $\pm \mathrm{S}$. E. M. of 3 independent experiments each carried out in triplicate; $\mathrm{P}<0.001$ by one-way ANOVA).

When $10 \mu \mathrm{M}$ dehydroascorbate was added to LDL that had been stored for 2 weeks at $4{ }^{\circ} \mathrm{C}$ in the presence of $100 \mu \mathrm{M}$ EDTA (to allow partial oxidation), it promoted oxidation of the particle upon exposure to $\mathrm{Cu}^{2+}$ ions (Fig 1B). In contrast, at higher concentrations (20-100 $\left.\mu \mathrm{M}\right)$, dehydroascorbate inhibited oxidation of the particle (Fig. 1B). We also measured the hydroperoxides generated in this LDL upon incubation with $\mathrm{Cu}^{2+}$, using a tri-iodide assay (Fig. 1C). A maximum of about 500-600 $\mathrm{nmol}$ of hydroperoxides/mg protein were produced in the LDL, compared with about 400-500 nmol of conjugated dienes (calculated from their molar absorption coefficient of $29,500 \mathrm{M}^{-1} \mathrm{~cm}^{-1}$ [59]). These values agree with previous estimates [32]. Similarly to the results when conjugated dienes were measured, a low concentration of dehydroascorbate $(10 \mu \mathrm{M})$ increased the rate of lipid hydroperoxide formation, whereas a higher concentration $(50 \mu \mathrm{M})$ completely inhibited the process (Fig. 1C).

We next examined the effects of adding dehydroascorbate at different stages during LDL oxidation by copper. Dehydroascorbate $(10 \mu \mathrm{M})$ added at zero time, before the addition of $\mathrm{Cu}^{2+}(5$ $\mu \mathrm{M}$ ), or during the early lag phase completely inhibited the formation of conjugated dienes for the duration of the experiment (Fig. $1 \mathrm{~A}$ and 2A). However, when dehydroascorbate was added during the mid lag phase, when the conjugated diene content of the LDL had reached only $\sim 2 \%$ of its maximum level, the propagation rate was increased by some $60 \%$. This switch from antioxidant to pro-oxidant behavior was remarkably sharp. For instance, in the experiment shown in Fig. 2A, dehydroascorbate behaved as a pro-oxidant when added after $26 \mathrm{~min}$, but displayed very effective 
antioxidant activity when added after $21 \mathrm{~min}$. A similar switch in behavior was also seen when using the lipid hydroperoxide assay. The addition of dehydroascorbate $(10 \mu \mathrm{M})$ to native $\mathrm{LDL}$ at time zero, before the addition of $\mathrm{Cu}^{2+}$, almost completely inhibited the formation of lipid hydroperoxides, but caused a marked enhancement in their formation when added during the mid lag-phase (Fig. 2B).

\section{Depletion of endogenous $\alpha$-tocopherol is not a prerequisite for the switch in behaviour of dehydroascorbate}

To investigate the possibility that the $\alpha$-tocopherol content of LDL determines whether dehydroascorbate behaves as an antioxidant or a pro-oxidant, freshly isolated LDL was stored at

$4^{\circ} \mathrm{C}$ in the presence of $100 \mu \mathrm{M}$ EDTA and tested daily for susceptibility to $\mathrm{Cu}^{2+}$-induced oxidation in the presence or absence of dehydroascorbate. This was continued until the compound switched from being an antioxidant to a pro-oxidant. Samples were also assayed for $\alpha$-tocopherol content. In the representative example shown in Fig. 3, dehydroascorbate $(10 \mu \mathrm{M})$ strongly inhibited the formation of conjugated dienes when added prior to $\mathrm{Cu}^{2+}$ on days $1-3$ following the isolation of the LDL (Fig. 3A). On day 4, however, dehydroascorbate switched to being a pro-oxidant for LDL (Fig. 3B). HPLC analysis of LDL samples taken before and after the antioxidant to pro-oxidant switch revealed that more than $80 \%$ of the original $\alpha$-tocopherol was still present in LDL when the switch occurred (Fig. 3C). These results show that the disappearance of endogenous $\alpha$ tocopherol is not a requirement for the switch to the pro-oxidant activity of dehydroascorbate.

\section{The pro-oxidant activity of dehydroascorbate is dependent on the presence of lipid}

\section{hydroperoxides}

We next investigated whether lipid hydroperoxides are required for dehydroascorbate to act as a pro-oxidant. As expected from the findings described above, the addition of dehydroascorbate 
$(10 \mu \mathrm{M})$ to native $\mathrm{LDL}(50 \mu \mathrm{g}$ protein/ml) at time zero completely prevented the induction of conjugated diene formation by $\mathrm{Cu}^{2+}$ (Fig. 4). The inclusion of a small amount of lipid hydroperoxide-rich LDL (5 $\mu \mathrm{g}$ protein/ml) in the incubation without dehydroascorbate decreased the lag phase before rapid oxidation (Fig. 4). Interestingly, the addition of dehydroascorbate (10 $\mu \mathrm{M})$ to incubations containing native LDL supplemented with lipid hydroperoxide-rich LDL resulted in a further shortening $(\sim 25 \%)$ of the lag phase and increased the propagation rate by almost $40 \%$ (Fig. 4).

Similar experiments were performed in which native LDL was spiked with the lipid hydroperoxide 13-HPODE instead of lipid hydroperoxide-rich LDL. Whereas dehydroascorbate $(10 \mu \mathrm{M})$ added at time zero completely inhibited the $\mathrm{Cu}^{2+}$-induced formation of conjugated dienes in the absence of 13-HPODE (Fig. 5A), a progressive reduction in the lag phase was seen in the presence of increasing amounts of the hydroperoxide. In the presence of 13-HPODE at a concentration of $10 \mathrm{nmol} / \mathrm{mg}$ LDL protein, $10 \mu \mathrm{M}$ dehydroascorbate completely inhibited the formation of conjugated dienes. However, as the concentration of the lipid hydroperoxide was increased to 20 and then $30 \mathrm{nmol} / \mathrm{mg}$ LDL protein, dehydroascorbate switched from antioxidant to pro-oxidant behavior. The effects of dehydroascorbate were again concentration-dependent. In the presence of 13-HPOPE at $20 \mathrm{nmol} / \mathrm{mg}$ LDL protein, $10 \mu \mathrm{M}$ dehydroascorbate had a pro-oxidant effect, whereas 30 or $100 \mu \mathrm{M}$ dehydroascorbate had a highly effective antioxidant effect (Fig. 5B).

\section{Dehydroascorbate serves as a pro-oxidant by reducing $\mathrm{Cu}^{2+}$ ions following its spontaneous conversion to ascorbate and erythroascorbate}

Having established that the pro-oxidant activity of dehydroascorbate toward $\mathrm{Cu}^{2+}$-challenged LDL particles requires the initial accumulation (or direct addition) of lipid hydroperoxides, we next employed a model alkyl hydroperoxide, ${ }^{t} \mathrm{BuOOH}$, to investigate in mechanistic detail the

interactions between $\mathrm{Cu}^{2+}$ ions, dehydroascorbate and alkyl hydroperoxides under relatively well 
defined, biomimetic conditions. In reactions analogous to those of the higher $M_{r}$ lipid hydroperoxides, ${ }^{t} \mathrm{BuOOH}$ undergoes catalytic decomposition to free radicals by redox-active metal ions in reactions that are amenable to study by EPR spectroscopy $[62,65]$. Since the resultant radicals are extremely unstable, this usually entails the use of a spin trap compound, such as the nitrone DMPO. Unstable free radicals add to the double bond in DMPO to form relatively stable nitroxide radical adducts, the EPR spectra of which provide information on the identity of trapped species [66].

The addition of $\mathrm{Cu}^{2+}$ to ${ }^{t} \mathrm{BuOOH}$ in the presence of DMPO resulted in the detection of an EPR spectrum containing a prominent signal from the tert-butoxyl radical $\left({ }^{t} \mathrm{BuO}{ }^{\circ}\right)$ adduct of the spin trap, together with weaker signals from the methyl ( $\left.{ }^{\circ} \mathrm{Me}\right)$ and methoxyl ( $\left.{ }^{\circ} \mathrm{OMe}\right)$ radical adducts (Fig. 6A). Although it has been widely assumed for many years that lipid hydroperoxides undergo a direct (albeit slow) oxidation by $\mathrm{Cu}^{2+}$ ions, to the corresponding peroxyl radicals, more recent EPR spin-trapping studies using ${ }^{t} \mathrm{BuOOH}$ have shown that alkyl hydroperoxides are in fact reduced by $\mathrm{Cu}^{2+}$ ions, giving alkoxyl radicals and $\mathrm{Cu}^{3+}[65]$. Thus, generation of the three radicals trapped and detected in the above reaction between $\mathrm{Cu}^{2+}$ and ${ }^{t} \mathrm{BuOOH}$ has been shown to result from the initial one-electron reduction of the peroxide (Reaction 1), followed by the $\beta$-scission (Reaction 2) and oxygenation (Reactions 3 - 5) of untrapped ${ }^{t} \mathrm{BuO}^{\circ}$ and ${ }^{\circ}$ Me radicals, respectively.

$$
\begin{aligned}
\mathrm{Cu}^{2+}+\left(\mathrm{CH}_{3}\right)_{3} \mathrm{COOH} & \rightarrow \mathrm{Cu}^{3+}+\left(\mathrm{CH}_{3}\right)_{3} \mathrm{CO}^{\cdot}+\mathrm{OH}^{-} \\
\left(\mathrm{CH}_{3}\right)_{3} \mathrm{CO} & \rightarrow{ }^{\circ} \mathrm{CH}_{3}+\left(\mathrm{CH}_{3}\right)_{2} \mathrm{C}=\mathrm{O} \\
\mathrm{O}_{2}+{ }^{\circ} \mathrm{CH}_{3} & \rightarrow{ }^{\circ} \mathrm{OOCH}_{3} \\
2{ }^{\circ} \mathrm{OOCH}_{3} & \rightarrow \mathrm{CH}_{3} \mathrm{OOOOOCH}_{3} \\
\mathrm{CH}_{3} \mathrm{OOOOCH}_{3} & \rightarrow 2{ }^{\circ} \mathrm{OCH}_{3}+\mathrm{O}_{2}
\end{aligned}
$$


The inclusion of ascorbic acid in the reaction system resulted in an increase in the intensity of the signals from the tert-butoxyl and methyl radical-adducts of DMPO (DMPO/ ${ }^{\circ} \mathrm{Bu}$ and DMPO/Me, respectively). If affected at all, the signal from the methoxyl adduct (DMPO/ $\left.{ }^{\circ} \mathrm{OMe}\right)$ was slightly reduced (Fig. 6B). These effects can be attributed to the rapid reduction of $\mathrm{Cu}^{2+}$ by ascorbate, giving $\mathrm{Cu}^{+}$, which reacts very rapidly with ${ }^{t} \mathrm{BuOOH}$ to initiate generation of the same radical species as when the reduction is brought about by $\mathrm{Cu}^{2+}$ (Reactions $6-8$, in which $\mathrm{AscH}^{-}$, $\mathrm{Asc}^{2-}$ and $\mathrm{Asc}^{\circ-}$ are the ascorbate monoanion, dianion and radical, respectively, and DHA is dehydroascorbate).

$$
\begin{aligned}
& \mathrm{AscH}^{-}\left(\mathrm{Asc}^{2-}+\mathrm{H}^{+}\right)+\mathrm{Cu}^{2+} \rightarrow \mathrm{Asc}^{--}+\mathrm{H}^{+}+\mathrm{Cu}^{+} \\
& \mathrm{Cu}^{+}+\left(\mathrm{CH}_{3}\right)_{3} \mathrm{COOH} \rightarrow \mathrm{Cu}^{2+}+\left(\mathrm{CH}_{3}\right)_{3} \mathrm{CO}^{\cdot}+\mathrm{OH}^{-} \\
& 2 \mathrm{Asc}^{--}+\mathrm{H}^{+} \rightarrow \mathrm{AscH}^{-}+\mathrm{DHA}
\end{aligned}
$$

The slight reduction in intensity of the DMPO/OMe signal, noted above, may reflect the reduction of ${ }^{\circ} \mathrm{OMe}$ by $\mathrm{Cu}^{+}$or ascorbate before reaction with the spin trap. Alternatively, this may reflect oxidation of the species by $\mathrm{Cu}^{2 / 3+}$ after undergoing a 1,2- $\mathrm{H}$ shift to the highly reducing ${ }^{\circ} \mathrm{CH}_{2} \mathrm{OH}$ radical [65]. Somewhat surprisingly, dehydroascorbate, despite being the two-electron oxidation product of ascorbate, was almost equally as effective as ascorbate in stimulating production of the $\mathrm{DMPO} /{ }^{\circ} \mathrm{O}^{t} \mathrm{Bu}$ and $\mathrm{DMPO} /{ }^{\circ} \mathrm{Me}$ radical adducts (Fig. $6 \mathrm{C}$ ). These findings suggest that dehydroascorbate brings about the reduction of $\mathrm{Cu}^{2+}$ to $\mathrm{Cu}^{+}$, which in turn reduces ${ }^{t} \mathrm{BuOOH}$ to the ${ }^{t} \mathrm{BuO}^{\circ}$ radical very rapidly. If this were the case, then we would expect to detect a dehydroascorbate-derived radical following electron transfer to the metal. Although very weak signals were detected when $\mathrm{Cu}^{2+}$ and dehydroascorbate were mixed in the presence of DMPO, without the peroxide (Fig. 6 D), subsequent experiments indicated that these were caused largely by $\mathrm{Cu}^{2+}$-catalyzed nucleophilic addition reactions, rather than the authentic generation of free 
radicals from dehydroascorbate (data not shown). Indeed, even in the absence of dehydroascorbate, $\mathrm{Cu}^{2+}$ catalyzed the nucleophilic addition of water to the spin trap, giving the DMPO hydroxyl radical-adduct (Fig. 6E), which is a well known reaction [67]. Interestingly, a weak doublet signal, characteristic of the ascorbate radical (a resonance-stablized radical that fails to react with spin traps) [68-70], was observed in the dehydroascorbate solution in the absence of both $\mathrm{Cu}^{2+}$ and DMPO (Fig. 6F), suggesting formation of the radical by a comproportionation reaction between dehydroascorbate and ascorbate, which is known to arise spontaneously from dehydroascorbate (Reaction -8)[45].

$$
\mathrm{DHA}+\mathrm{AscH}^{-} \rightarrow 2 \mathrm{Asc}^{{ }^{-}}+\mathrm{H}^{+}
$$

Although the rate constant for the spontaneous disproportionation of ascorbate radicals is high $\left(k_{8} \sim 10^{5}-10^{6} \mathrm{M}^{-1} \mathrm{~s}^{-1}\right.$ in the physiological $\mathrm{pH}$ range) $[68,71]$, at very low concentrations the reaction rate will be slow (being proportional to $\left[\mathrm{Asc}^{\circ-}\right]^{2}$ ) and in equilibrium with the reverse reaction (Reaction -8$)$.

In order to detect directly any short-lived radicals generated in the reduction of $\mathrm{Cu}^{2+}$ by dehydroascorbate, continuous-flow EPR spectroscopy was employed. This involves the mixing of the reactant solutions just as they enter the EPR cavity, thereby allowing the direct observation of any radicals formed over the millisecond time scale without the use of a spin trap: although each individual radical will decay rapidly, it is replaced immediately as fresh reagent enters the cavity, thereby achieving a detectable steady-state concentration of radicals $[62,72]$. The continuous mixing of $\mathrm{Cu}^{2+}$ and dehydroascorbate in the EPR cavity resulted in the detection of a prominent doublet signal, which was seen to decrease in intensity as the rate at which the reactants were flowed through the cavity was lowered (Fig. 7A). This signal is essentially identical to that of the 
ascorbate radical [68-70], which for comparison was generated in the reaction between $\mathrm{Cu}^{2+}$ and ascorbate (Reaction 6) (Fig. 7B).

Czapski has proposed mathematical models for the generation and decay of radicals in EPR continuous-flow systems [72]. In one extreme case, when the rate of radical generation reaction is low, it is assumed that a true steady state concentration of radicals exists at the point in the flow cell at which the spectrum is recorded, i.e. radical generation is still underway when the mixed reagents have reached the observation point. In the other extreme case, the initial reaction is very fast and assumed to be completed immediately after the reagents have been mixed, as expected for the reaction between $\mathrm{Cu}^{2+}$ and ascorbate. In this case, the concentration of radicals detected is determined only by their rate of decay and would be described, in the system studied here, by the equation,

$$
1 /\left[\mathrm{Asc}^{{ }^{-}}\right]_{t}=2 k_{8} t+1 /\left[\mathrm{Asc}^{{ }^{-}}\right]_{0}
$$

where $\left[\mathrm{Asc}^{-{ }^{-}}\right]_{t}$ is the concentration of ascorbate radicals $t$ seconds after the reagents have been mixed (i.e., the delay time between reactant mixing and the point of EPR observation in the flow system) and $\left[\mathrm{Asc}^{-{ }^{-}}\right]_{\mathrm{o}}$ is the initial ascorbate radical concentration $(t=$ zero). The validity of this equation was tested by plotting the reciprocal of the EPR signal height (the EPR signal height is proportional to $\left[\mathrm{Asc}^{-}\right]$) against $t$ for the data points obtained during the initial, rapid phase of ascorbate radical decay (within the first $45 \mathrm{~ms}$ ), which gave the expected straight-line fit (Fig. 7C). Having established that the reaction between $\mathrm{Cu}^{2+}$ and ascorbate is essentially 'instantaneous' under the pseudo first-order conditions employed, it was assumed that the concentration of ascorbate radicals at $t=0$ is equal to the initial, post-mixing concentration of $\mathrm{Cu}^{2+}$ ions, which was $2.5 \mathrm{mM}$. Therefore, using the value from the $y$-axis intercept of the reciprocal plot (Fig. 7C), EPR signal heights (in arbitrary units) were converted to ascorbate radical concentrations, as given on the $y$-axis of Fig. 7B. From the gradient of the plot given in Figure 7C (after conversion of signal heights to concentration units), $2 k_{8}$ was estimated to be $\approx 10^{5} \mathrm{M}^{-1} \mathrm{~s}^{-1}$, which is in reasonable 
agreement with the values reported in the literature $[68,71]$, thereby supporting the kinetics approach used above to obtain ascorbate radical concentrations from EPR signal intensities.

Although the EPR signal observed upon the reaction of $\mathrm{Cu}^{2+}$ and dehydroascorbate appears to be identical to that of the ascorbate radical, we suggest that this is in fact the erythroascorbate radical (Fig. 7A). Jung and Wells have demonstrated that in aqueous solution dehydroascorbate undergoes spontaneous conversion to at least three products, which include ascorbate and erythroascorbate [45]; other studies have also demonstrated such reactions [43, 44]. The radicals generated upon the one-electron oxidation of ascorbate and erythroascorbate would be expected to give essentially identical EPR spectra under the conditions employed in 
this study ${ }^{1}$, therefore it was considered acceptable to assume the same signal height-to-radical concentration relationship for erythroascorbate radicals as determined for ascorbate radicals, giving the signal calibration indicated in Fig. 7A. Since the amount of ascorbate generated spontaneously from dehydroascorbate is much smaller than the amount of erythroascorbate formed [45], it is concluded on kinetics grounds that the erythroascorbate radical is the major species detected in the $\mathrm{Cu}^{2+}$-dehydroascorbate reaction system (Fig. 7A). M aking the reasonable assumption that $\mathrm{Cu}^{2+}$ reacts with ascorbate and erythroascorbate with similar rate constants, then the latter would be the major species oxidised when present in large excess over the former. This suggests that erythroascorbate, generated by the spontaneous interconversion mechanism identified by Jung and Wells [45], is responsible for the ability of dehydroascorbate solutions to reduce $\mathrm{Cu}^{2+}$ ions. Complementary experiments using BCDS, which forms a stable, coloured complex with $\mathrm{Cu}^{+}$ions, showed that dehydroascorbate solutions bring about the reduction of $\mathrm{Cu}^{2+}$ to $\mathrm{Cu}^{+}$(data not shown). However, since chelation by BCDS increases the reduction potential of the $\mathrm{Cu}^{2+} / \mathrm{Cu}^{+}$couple by approximately $0.5 \mathrm{~V}$ [73], this finding is of limited relevance to situations in which $\mathrm{Cu}^{2+}$ is less oxidizing (e.g., when bound to amino acids, peptides and biological buffers).

\section{DISCUSSION}

The mechanisms by which $\mathrm{Cu}^{2+}$ ions initiate and propagate the oxidation of LDL remain a matter of contention [12]. Both $\alpha$-tocopheroxyl ( $\alpha$-Toc- $\left.0^{\circ}\right)$ and hydroxyl ( $\left.{ }^{\circ} \mathrm{OH}\right)$ radicals have been suggested to be responsible for the initiation of polyunsaturated fatty acid oxidation within LDL. The former species, generated upon the oxidation of $\alpha$-tocopherol by $\mathrm{Cu}^{2+}$ (Reaction 9), is

\footnotetext{
${ }^{1}$ The predominant doublet hyperfine structure of the signal from the ascorbate radical [70] I. Yamazaki, in Foundations of Modern EPR G. R. Eaton, S. S. Eaton, K. M. Salikhov, Eds. (World Scientific Publishing, London, 1998) pp. 436-450. arises from coupling to the hydrogen at $\mathrm{C} 4\left(a^{\mathrm{H}-4}=1.75 \mathrm{G}\right)$. Further splitting (though rarely resolved) arises through interaction with the two equivalent hydrogens at $\mathrm{C} 6\left(a^{2 \mathrm{H}-6}=0.19 \mathrm{G}\right)$ in the hemiketal form. Both of these couplings are possible in the corresponding erythroascorbate radical, where the two equivalent hydrogens would be on C5 instead of C6. The only difference expected would result from the absence of interaction with a third hydrogen (C5 in the ascorbate radical), which results in only an extremely small splitting $\left(a^{\mathrm{H}-5}=0.06 \mathrm{G}\right)$, the absence of which would be barely detectable in the spectrum of the erythroascorbate radical.
} 
believed to be capable of $\mathrm{H}$-atom abstraction from the bisallylic methylene groups (LH) of polyunsaturated fatty acids (Reaction 10) [33].

$$
\begin{aligned}
& \mathrm{Cu}^{2+}+\alpha-\text {-Toc-OH } \longrightarrow \mathrm{Cu}^{+}+\alpha-\text {-Toc-O }+\mathrm{H}^{+} \\
& \alpha-\mathrm{Toc}^{\bullet}+\mathrm{LH} \longrightarrow \alpha-\mathrm{Toc}-\mathrm{OH}+\mathrm{L}^{\bullet}
\end{aligned}
$$

Since this reaction is extremely slow $\left(k_{10} \approx 0.1 \pm 0.05 \mathrm{M}^{-1} \mathrm{~s}^{-1}\right.$ at $\left.37{ }^{\circ} \mathrm{C}\right)$, it has been suggested that the much more reactive ${ }^{\circ} \mathrm{OH}$ radical, generated via the sequential reduction of molecular oxygen by $\mathrm{Cu}^{+}$, is the species responsible for the initiation of LDL oxidation (Reactions 11-15, showing both the initial one- and two-electron oxygen reduction pathways) [12, 74].

$$
\begin{aligned}
& \mathrm{Cu}^{+}+\mathrm{O}_{2} \longrightarrow \mathrm{Cu}^{2+}+\mathrm{O}_{2}^{2^{-}} \\
& 2 \mathrm{O}_{2}^{*^{-}}+2 \mathrm{H}^{+} \longrightarrow \mathrm{H}_{2} \mathrm{O}_{2}+\mathrm{O}_{2} \\
& \mathrm{Cu}^{+}+\mathrm{O}_{2}^{{ }^{-}}+2 \mathrm{H}^{+} \longrightarrow \mathrm{Cu}^{2+}+\mathrm{H}_{2} \mathrm{O}_{2} \\
& 2 \mathrm{Cu}^{+}+\mathrm{O}_{2}+2 \mathrm{H}^{+} \longrightarrow 2 \mathrm{Cu}^{2+}+\mathrm{H}_{2} \mathrm{O}_{2} \\
& \mathrm{Cu}^{+}+\mathrm{H}_{2} \mathrm{O}_{2} \longrightarrow \mathrm{Cu}^{2+}+{ }^{\circ} \mathrm{OH}+\mathrm{OH}^{-}
\end{aligned}
$$

The ${ }^{\circ} \mathrm{OH}$ radical is expected to initiate fatty acid oxidation via addition to the bisallylicmethylene double bonds and via $\mathrm{H}$-atom abstraction, both of which yield carbon-centred radicals (Reactions 16a and 16b, respectively) [75].

$$
\begin{aligned}
& { }^{\circ}+\mathrm{LH} \longrightarrow(\mathrm{HO}) \mathrm{HL}^{\bullet} \\
& { }^{\circ} \mathrm{OH}+\mathrm{LH} \longrightarrow \mathrm{L}^{\cdot}+\mathrm{H}_{2} \mathrm{O}
\end{aligned}
$$


Both $\mathrm{L}^{\bullet}$ and (HO) $\mathrm{HL}^{\circ}$ will add oxygen to give the corresponding peroxyl radicals and, via subsequent $\mathrm{H}$-atom abstraction, their hydroperoxides (Reactions 17-18 and 19-20, respectively).

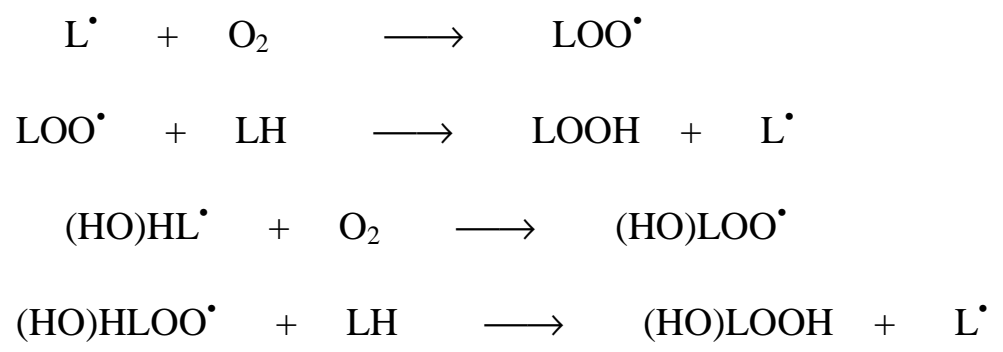

We postulate that:

(i) the pro-oxidant activity of dehydroascorbate is related to its ability to reduce $\mathrm{Cu}^{2+}$ to $\mathrm{Cu}^{+}$(involving spontaneous conversion to ascorbate and erythroascorbate) and

(ii) the pro-oxidant behavior of dehydroascorbate is dependent on the presence of lipid hydroperoxides.

It could be argued that, through their rapid reduction of $\mathrm{Cu}^{2+}$, ascorbate and erythroascorbate prevent generation of the initiating $\alpha$-Toc $\mathrm{O}^{\bullet}$ radical from endogenous $\alpha$-tocopherol via Reaction 9 (Reactions 6 and 21, respectively, in which E-AscH ${ }^{-}, \mathrm{E}_{-} \mathrm{Asc}^{2-}$ and $\mathrm{E}-\mathrm{Asc}^{--}$are the erythroascorbate monoanion, dianion and radical, respectively).

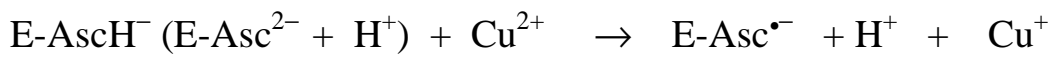

Since the rate constant for the reaction of $\mathrm{Cu}^{2+}$ with ascorbate $\left(k_{6} \sim 880 \mathrm{M}^{-1} \mathrm{~s}^{-1}\right)$ [76] is some 1500 times higher than that for the corresponding reaction with $\alpha$-tocopherol $\left(k_{9} \sim 0.56 \mathrm{M}^{-1} \mathrm{~s}^{-1}\right)$ [77], it is reasonable to assume that ascorbate, and the chemically-similar erythroascorbate, will out-compete $\alpha$-tocopherol for reaction with the metal. In arguing that the protection afforded by dehydroascorbate is due to its diversion of $\mathrm{Cu}^{2+}$ away from reaction with $\alpha$-tocopherol, it would 
be necessary to assume that ${ }^{\circ} \mathrm{OH}$ radicals, generated from oxygen upon reduction by the $\mathrm{Cu}^{+}$ generated in Reactions 6 and 21, do not play a significant role in the initiation of LDL oxidation. However, following the accumulation of lipid hydroperoxides, $\mathrm{Cu}^{+}$would assume a pro-oxidant role in the generation of reactive, chain-propagating alkoxyl radicals (Reaction 22, analogous to Reaction 7).

$$
\mathrm{Cu}^{+}+\mathrm{LOOH} \longrightarrow \mathrm{Cu}^{2+}+\mathrm{LO}^{+}+\mathrm{OH}^{-}
$$

Although the above interpretation takes account of postulates (i) and (ii), a further postulate must be made to account for the fact that dehydroascorbate behaves as a pro-oxidant only at low concentrations (Fig. 1B, C and 5B). At high concentrations, any pro-oxidant activity resulting from the ability of dehydroascorbate to generate $\mathrm{Cu}^{+}$for reaction with lipid hydroperoxides must be overwhelmed by an antioxidant action. One possibility is that the ascorbate and erythroascorbate derived from dehydroascorbate act as radical-scavenging antioxidants. Indeed, the finding that around $80 \%$ of the original $\alpha$-tocopherol was still present in the LDL when it contained sufficient lipid hydroperoxide to allow dehydroascorbate to behave as a pro-oxidant (Fig. 3) allows for the possibility of lipid-radical scavenging by $\alpha$-tocopherol, with its regeneration from the $\alpha$-tocopheroxyl radical by ascorbate and erythroascorbate across the phase boundary [78].

An additional mechanism by which dehydroascorbate could serve as an antioxidant involves its interference with copper binding to LDL, which has been reported to be necessary for oxidation of the particle [27]. This view is supported by our finding that dehydroascorbate decreased the binding of copper to LDL. This could entail either the chelation of copper ions by dehydroascorbate (or its degradation products) or the modification of LDL such that it has reduced ability to bind the metal ion. The latter possibility has been raised already by Retsky et al., who 
suggested that apo B100 may undergo a stable modification by dehydroascorbate or its degradation products [24].

It is also necessary to account for the ability of dehydroascorbate at all concentrations tested to prevent the initiation of fatty acid oxidation in LDL not already containing significant lipid hydroperoxide (Fig. 1A). The protection afforded to native LDL by dehydroascorbate is absolute: there is not even a gradual increase in conjugated diene formation over the 120 min incubation period, even with only $10 \mu \mathrm{M}$ dehydroascorbate (Fig. 1A). This argues against radical scavenging by dehydroascorbate, which would simply extend the lag phase in the same way as other antioxidants of this type $[32,64]$. Instead, we suggest that dehydroascorbate prevents the actual formation of the species responsible for the initiation of LDL oxidation. Whilst we have described how ascorbate and erythroascorbate derived from dehydroascorbate may achieve this by competing with $\alpha$-tocopherol for oxidation by $\mathrm{Cu}^{2+}$, thereby preventing formation of the $\alpha$-Toc-O radical, it seems unlikely that LDL would not begin to oxidise eventually because dehydroascorbate would be depleted through this process (quickly at the $\mathrm{Cu}^{2+}$ concentrations employed).

Taking, instead, the alternative view, that the $\alpha-$ Toc-O$^{\bullet}$ radical is not responsible for the initiation of lipid peroxidation in native LDL, it has to be assumed that it is the $\mathrm{Cu}^{+}$formed upon reaction of the added $\mathrm{Cu}^{2+}$ with endogenous $\alpha$-tocopherol that is responsible for the generation of a powerful oxidant. In native LDL that is low in lipid hydroperoxides, oxidation will be initiated by the ${ }^{\circ} \mathrm{OH}$ radical, formed via the reduction of oxygen by $\mathrm{Cu}^{+}$according to Reactions 11-15 [12, 74]. Dehydroascorbate may compete with oxygen as the electron acceptor from $\mathrm{Cu}^{+}$(Reaction 23 ).

$$
\mathrm{DHA}+\mathrm{Cu}^{+} \rightarrow \mathrm{Asc}^{--}+\mathrm{Cu}^{2+}
$$


The equilibrium position of this reaction would be shifted to the right by the disproportionation of ascorbate radicals (Reaction 8). Thus dehydroascorbate may prevent the reduction of oxygen to the hydroxyl radical (Reactions 11-16). Given the similarity between the reduction potentials of the DHA/Asc ${ }^{\circ-}$ couple $\left(E^{\circ}=-0.174 \mathrm{~V}\right)$ [79], which prevails at physiological $\mathrm{pH}$ (the $\mathrm{p} K_{\mathrm{a}}$ of the ascorbate radical is $-0.45[79])$, and that of the $\mathrm{O}_{2}(1 \mathrm{M}) / \mathrm{O}_{2}{ }^{--}$couple $\left(E^{\mathrm{o}^{\prime}}=-0.179 \mathrm{~V}\right.$ at $\left.\mathrm{pH} 7\right)$ [80], it is quite feasible that excess dehydroascorbate may prevent oxygen reduction by competing for the electron from $\mathrm{Cu}^{+}$(Reaction 23). The spontaneous conversion of dehydroascorbate to ascorbate and erythroascorbate would also protect by scavenging ${ }^{\circ} \mathrm{OH}$ radicals.

Dehydroascorbate would not, however, be expected to compete with lipid hydroperoxides for reduction by $\mathrm{Cu}^{+}$, simply because the $\mathrm{LOOH} / \mathrm{LO}^{\circ}, \mathrm{OH}^{-}$couple is far more oxidizing $\left(E^{\circ} \sim 1.0\right.$ V) [81]. As a result, the pro-oxidant, reducing properties of dehydroascorbate will prevail in the presence of lipid hydroperoxides.

In summary, we have shown that dehydroascorbate displays dual, antioxidant/pro-oxidant behavior in $\mathrm{LDL}$ challenged with $\mathrm{Cu}^{2+}$. The switch from antioxidant to pro-oxidant behavior occurs only in the presence of preformed lipid hydroperoxides. If added to native LDL, dehydroascorbate at all concentrations is protective because it prevents the initiation of lipid peroxidation by the mechanisms proposed above. As a result, the lipid hydroperoxides needed for dehydroascorbate to act as a pro-oxidant are not generated. The pro-oxidant action of dehydroascorbate can be best explained in terms of its provision of $\mathrm{Cu}^{+}$ions for the rapid decomposition of lipid hydroperoxides to chain-propagating alkoxyl radicals. This provision of $\mathrm{Cu}^{+}$most likely involves the spontaneous conversion of DHA to the reductants erythroascorbate and ascorbate. Theses reactions are shown schematically in Scheme 1.

Our findings suggest that dehydroascorbate has the potential to increase the oxidation of mildly-oxidised LDL in atherosclerotic lesions. Further studies will be needed, however, to determine if this applies in vivo. 
This research was funded by grants from the Ministry of Agriculture, Fisheries and Food (United Kingdom) and Cancer Research UK. 


\section{RERERENCES}

[1] G. M. Chisolm, D. Steinberg, Free Radical Biol. Med. 28 (2000) 1815-1826.

[2] D. Steinberg, J. L. Witztum, Circulation 105 (2002) 2107-2111.

[3] J. W. Heinecke, H. Rosen, A. Chait, J. Clin. Invest. 74 (1984) 1890-1894.

[4] D. S. Leake, S. M. Rankin, Biochem. J. 270 (1990) 741-748.

[5] U. P. Steinbrecher, S. Parthasarathy, D. S. Leake, J. L. Witztum, D. Steinberg, Proc. Natl. Acad. Sci. U.S.A. 81 (1984) 3883-3887.

[6] K. Müller, K. L. H. Carpenter, M. J. Mitchinson, Free Radical Res. 29 (1998) 207-220.

[7] G. M. I. Chisolm, S. L. Hazen, P. L. Fox, M. K. Cathcart, J. Biol. Chem. 274 (1999) 25959-25962.

[8] R. Stocker, J. F. Keaney, Physiol. Rev. 84 (2004) 1381-1478.

[9] L. Kritharides, W. Jessup, R. T. Dean, Arch. Biochem. Biophys. 323 (1995) 127-136.

[10] B. Garner, D. vanReyk, R. T. Dean, W. Jessup, J. Biol. Chem. 272 (1997) 6927-6935.

[11] A. Graham, Free Radical Res. 28 (1998) 611-621.

[12] M. J. Burkitt, Arch. Biochem. Biophys. 394 (2001) 117-135.

[13] E. Ehrenwald, G. M. Chisolm, P. L. Fox, J. Clin. Invest. 93 (1994) 1493-1501.

[14] D. J. Lamb, D. S. Leake, FEBS Lett. 338 (1994) 122-126.

[15] C. K. Mukhopadhyay, P. L. Fox, Biochemistry 37 (1998) 14222-14229.

[16] C. Smith, M. J. Mitchinson, O. I. Aruoma, B. Halliwell, Biochem. J. 286 (1992) 901-905.

[17] S. Fu, M. J. Davies, R. Stocker, R. T. Dean, Biochem. J. 333 (1998) 519-525.

[18] J. Pietzsch, R. Bergmann, S. Kopprasch, Spectr.-Int. J. 18 (2004) 177-183.

[19] N. Stadler, R. A. Lindner, M. J. Davies, Arterioscler. Thromb. Vasc. Biol. 24 (2004) 949954.

[20] M. G. L. Hertog, D. Kromhout, C. Aravanis, H. Blackburn, R. Buzina, F. Fidanza, S. Giampaoli, A. Jansen, A. Menotti, S. Nedeljkovic, M. Pekkarinen, B. S. Simic, H.

Toshima, E. J. M. Feskens, P. C. H. Hollman, M. B. Katan, Arch. Intern. Med. 155 (1995) 381-386.

[21] K. F. Gey, Br. Med. Bull. 49 (1993) 679-699.

[22] V. W. Bowry, K. U. Ingold, R. Stocker, Biochem. J. 288 (1992) 341-344.

[23] A. Baoutina, R. T. Dean, W. Jessup, J. Lipid Res. 39 (1998) 114-130.

[24] K. L. Retsky, M. W. Freeman, B. Frei, J. Biol. Chem. 268 (1993) 1304-1309.

[25] Stait, S.E., D. S. Leake, FEBS Lett. 341 (1994) 263-267.

[26] S. E. Stait, D. S. Leake, Biochem. J. 320 (1996) 373-381.

[27] K. L. Retsky, K. Chen, J. Zeind, B. Frei, Free Radical Biol. Med. 26 (1999) 90-98.

[28] C. V. de Whalley, S. M. Rankin, J. R. S. Hoult, W. Jessup, D. S. Leake, Biochem. Pharmacol. 39 (1990) 1743-1750.

[29] L. Mathiesen, K. E. Malterud, M. S. Nenseter, R. B. Sund, Pharmacol. Toxicol. 78 (1996) 143-146.

[30] N. Yamanaka, O. Oda, S. Nagao, FEBS Lett. 401 (1997) 230-234.

[31] J. E. Brown, C. A. Rice-Evans, Free Radical Res. 29 (1998) 247-255.

[32] H. Esterbauer, J. Gebicki, H. Puhl, G. Jürgens, Free Radical Biol. Med. 13 (1992) 341-390.

[33] K. U. Ingold, V. W. Bowry, R. Stocker, C. Walling, Proc. Natl. Acad. Sci. U.S.A. 90 (1993) 45-49.

[34] V. W. Bowry, R. Stocker, J. Am. Chem. Soc. 115 (1993) 6029-6044.

[35] P. Otero, M. Viana, E. Herrera, B. Bonet, Free Radical Res. 27 (1997) 619-626.

[36] R. Briante, F. Febbraio, R. Nucci, Chem. Biodivers. 1 (2004) 1716-1729.

[37] S. M. Lynch, B. Frei, Biochim. Biophys. Acta 1345 (1997) 215-221.

[38] R. A. Patterson, D. J. Lamb, D. S. Leake, Atherosclerosis 169 (2003) 87-94.

[39] P. M. Abuja, FEBS Lett. 446 (1999) 305-308. 
[40] M. Bagnati, C. Perugini, C. Cau, R. Bordone, E. Albano, G. Bellomo, Biochem. J. 340 (1999) 143-152.

[41] R. A. Patterson, E. T. M. Horsley, D. S. Leake, J. Lipid Res. 44 (2003) 512-521.

[42] K. L. Retsky, B. Frei, Biochim. Biophys. Acta 1257 (1995) 279-287.

[43] E. Kimoto, H. Tanaka, T. Ohmoto, M. Choami, Anal. Biochem. 214 (1993) 38-44.

[44] J. C. Deutsch, Anal. Biochem. 247 (1997) 58-62.

[45] C.-H. Jung, W. W. Wells, Arch. Biochem. Biophys. 355 (1998) 9-14.

[46] G. L. W. Simpson, B. J. Ortwerth, Biochim. Biophys. Acta 1501 (2000) 12-24.

[47] D. Every, Anal. Biochem. 242 (1996) 234-239.

[48] B. D. Cox, M. J. Whichelow, Biochem. Med. 12 (1975) 183-193.

[49] S. Som, S. Basu, D. Mukherjee, S. Deb, P. R. Choudhury, S. Mukherjee, S. N. Chatterjee, I. B. Chatterjee, Metab.-Clin. Exp. 30 (1981) 572-577.

[50] L. Stankova, M. Riddle, J. Larned, K. Burry, D. Menashe, J. Hart, R. Bigley, Metab.-Clin. Exp. 33 (1984) 347-353.

[51] J. Lunec, D. R. Blake, Free Radical Res. Comm. 1 (1985) 31-39.

[52] A. J. Sinclair, A. J. Girling, L. Gray, C. Leguen, J. Lunec, A. H. Barnett, Diabetologia 34 (1991) 171-175.

[53] M. Kim, M. Otsuka, R. Yu, T. Kurata, N. Arakawa, Int. J. Vitam. Nutr. Res. 64 (1994) 5659.

[54] J. Lykkesfeldt, S. Loft, J. B. Nielsen, H. E. Poulsen, Am. J. Clin. Nutr. 65 (1997) 959-963.

[55] C. Suarna, R. T. Dean, J. May, R. Stocker, Arterioscler. Thromb. Vasc. Biol. 15 (1995) 1616-1624.

[56] G. M. Wilkins, D. S. Leake, Biochim. Biophys. Acta 1211 (1994) 69-78.

[57] G. R. Schacterle, R. L. Pollack, Anal. Biochem. 51 (1973) 654-655.

[58] L. K. Harris, G. E. Mann, E. Ruiz, S. Mushtaq, D. S. Leake, Arch. Biochem. Biophys. 455 (2006) 68-76.

[59] H. Esterbauer, G. Striegl, H. Puhl, M. Rotheneder, Free Radical Res. Comm. 6 (1989) 6775.

[60] M. El-Saadani, H. Esterbauer, M. El-Sayed, M. Goher, A. Y. Nassar, G. Jürgens, J. Lipid Res. 30 (1989) 627-630.

[61] A. Roland, R. A. Patterson, D. S. Leake, Arterioscler. Thromb. Vasc. Biol. 21 (2001) 594602.

[62] C. M. Jones, M. J. Burkitt, J. Chem. Soc.-Perkin Trans. 2 (2002) 2044-2051.

[63] S. M. Lynch, B. Frei, J. Biol. Chem. 270 (1995) 5158-5163.

[64] E. Cadenas, H. Sies, Free Radical Res. 28 (1998) 601-609.

[65] C. M. Jones, M. J. Burkitt, J. Am. Chem. Soc. 125 (2003) 6946-6954.

[66] R. P. Mason, P. M. Hanna, M. J. Burkitt, M. B. Kadiiska, Environ. Health Perspect. 102 (1994) 33-36.

[67] M. J. Burkitt, S. Y. Tsang, S. C. Tam, I. Bremner, Arch. Biochem. Biophys. 323 (1995) 63-70.

[68] M. J. Burkitt, B. C. Gilbert, Free Radical Res. Comm. 10 (1990) 265-280.

[69] G. R. Buettner, B. A. Jurkiewicz, Free Radical Biol. Med. 14 (1993) 49-55.

[70] I. Yamazaki, in Foundations of Modern EPR G. R. Eaton, S. S. Eaton, K. M. Salikhov, Eds. (World Scientific Publishing, London, 1998) pp. 436-450.

[71] B. H. J. Bielski, A. O. Allen, H. A. Schwarz, J. Am. Chem. Soc. 103 (1981) 3516-3518.

[72] G. Czapski, J. Phys. Chem. 75 (1971) 2957- 2967.

[73] L. M. Sayre, Science 274 (1996) 1933-1934.

[74] M. J. Burkitt, L. Milne, FEBS Lett. 379 (1996) 51-54.

[75] C. von Sonntag, The Chemical Bais of Radiation Biology (Taylor \& Francis, London, 1987). 
[76] G. R. Buettner, J. Biochem. Biophys. Methods 16 (1988) 27-40.

[77] Y. Yoshida, J. Tsuchiya, E. Niki, Biochim. Biophys. Acta 1200 (1994) 85-92.

[78] G. R. Buettner, Arch. Biochem. Biophys. 300 (1993) 535-543.

[79] N. H. Williams, J. K. Yandell, Aust. J. Chem. 35 (1982) 1133-1144.

[80] P. Wardman, Free Radical Res. Comm. 14 (1991) 57-67.

[81] W. H. Koppenol, FEBS Lett. 264 (1990) 165-167. 


\section{FIGURE LEGENDS}

Figure 1. Effects of dehydroascorbate on the oxidation of native and mildly oxidised LDL. A. Native LDL (50 $\mu \mathrm{g}$ protein $/ \mathrm{ml})$ in $\mathrm{PBS}$ was incubated at $37^{\circ} \mathrm{C}$ with $\mathrm{CuSO}_{4}(5 \mu \mathrm{M}$ net) (O). Dehydroascorbate (DHA) was added at zero time at concentrations of $10 \mu \mathrm{M}(\bullet), 20 \mu \mathrm{M}(\mathrm{X})$ or $100 \mu \mathrm{M}(\mathbf{\square})$. B. The same LDL preparation as that shown in A was left to become partially oxidised by storage at $4^{\circ} \mathrm{C}$ in the presence of $100 \mu \mathrm{M}$ EDTA for 2 weeks. LDL (50 $\mu \mathrm{g}$ protein $\left./ \mathrm{ml}\right)$ in PBS was oxidised by the addition of $\mathrm{CuSO}_{4}(5 \mu \mathrm{M}$ net $)$ at $37^{\circ} \mathrm{C}(\mathrm{O})$. Dehydroascorbate was added at zero time at concentrations of $10 \mu \mathrm{M}(\bullet), 20 \mu \mathrm{M}(\mathbf{X}), 40 \mu \mathrm{M}(\mathbf{\square}), 80 \mu \mathrm{M}(\square)$ or $100 \mu \mathrm{M}$ (4). C. The same batch of LDL as that shown in A was stored at $4^{\circ} \mathrm{C}$ in the presence of $100 \mu \mathrm{M}$ EDTA for 2 weeks and incubated in triplicate at $37^{\circ} \mathrm{C}$ at $100 \mu \mathrm{g}$ protein $/ \mathrm{ml}$ (rather than $50 \mu \mathrm{g}$ protein/ml, as the lipid hydroperoxide assay is less sensitive than the conjugated diene assay) with $\mathrm{CuSO}_{4}(10 \mu \mathrm{M}$ net) (O). Dehydroascorbate was added at zero time at concentrations of $10 \mu \mathrm{M}$ $(\bullet)$ or $50 \mu \mathrm{M}(\mathbf{X})$ and samples $(25 \mu \mathrm{g})$ were removed every 15 minutes and the oxidation halted with butylated hydroxytoluene $(20 \mu \mathrm{M}$, final $)$ and EDTA $(1 \mathrm{mM}$, final). The samples were assayed for lipid hydroperoxides. The means \pm S.E.M. for the triplicate samples are shown, except where the error bar is smaller than the symbol. These results were confirmed by two other experiments.

Figure 2. Effect of time of addition of dehydroascorbate on LDL oxidation. A. Native LDL (50 $\mu \mathrm{g}$ protein/ml) in PBS was incubated with $\mathrm{CuSO}_{4}(5 \mu \mathrm{M}$ net) (O). Dehydroascorbate (DHA; 10 $\mu \mathrm{M})$ was added at zero time $(\mathbf{X}), 4 \min (\mathbf{\square}), 8 \min (\square), 12 \min (\triangle), 16 \min (\mathbf{\Delta})$ or $21 \min (+)$ or during the mid lag phase at $26 \min (\bullet)$, and the formation of conjugated dienes monitored. The results are expressed as the change in $\mathrm{A}_{234}$ and were confirmed by two other experiments. $\mathrm{B}$. Native LDL $(100 \mu \mathrm{g}$ protein $/ \mathrm{ml})$ in PBS was incubated in triplicate at $37^{\circ} \mathrm{C}$ with $\mathrm{CuSO}_{4}(10 \mu \mathrm{M}$ net) (O). Dehydroascorbate (DHA; $10 \mu \mathrm{M})$ was added at zero time $(\bullet)$ or during the mid lag 
phase at $27 \min (\times)$. Samples $(25 \mu \mathrm{g})$ were removed every 15 minutes, the oxidation halted with butylated hydroxytoluene $(20 \mu \mathrm{M})$ and EDTA $(1 \mathrm{mM})$ and a lipid hydroperoxide assay carried out. The means \pm S.E.M. for the triplicate samples are shown, except where the error bars are smaller than the symbols. These results were confirmed by two other experiments.

Figure 3. $\alpha$-Tocopherol depletion does not determine the antioxidant to pro-oxidant switch for dehydroascorbate. LDL was stored at $4^{\circ} \mathrm{C}$ in the presence of $100 \mu \mathrm{M}$ EDTA. Each day a sample of $\operatorname{LDL}(50 \mu \mathrm{g}$ protein/ml $)$ in PBS was incubated at $37^{\circ} \mathrm{C}$ with $\mathrm{CuSO}_{4}(5 \mu \mathrm{M}$ net $)(\diamond)$. Dehydroascorbate (DHA; $10 \mu \mathrm{M})$ was added at time zero $(\square)$ and the formation of conjugated dienes monitored. Dehydroascorbate displayed antioxidant activity toward LDL stored for up to three days (A), but behaved as a pro-oxidant after LDL storage for four days (B). The results are expressed as the change in $\mathrm{A}_{234}$. The $\alpha$-tocopherol in LDL was extracted in triplicate and measured by HPLC (C). The results are means \pm S.E.M. of triplicates. Similar results were observed in two other experiments, except that in one experiment the dehydroascorbate switched to pro-oxidant behavior on day 8 following the isolation of LDL.

Figure 4. The effect of lipid hydroperoxide-rich LDL on the antioxidant to pro-oxidant switch for dehydroascorbate. Native LDL (50 $\mu \mathrm{g}$ protein/ml) in $\mathrm{PBS}$ was incubated at $37^{\circ} \mathrm{C}$ with $\mathrm{CuSO}_{4}$ $(5 \mu \mathrm{M}$ net) (O). Dehydroascorbate (DHA; $10 \mu \mathrm{M})(\bullet)$ or lipid hydroperoxide-rich LDL (LOOHLDL), containing $206 \mathrm{nmol}$ lipid hydroperoxides/mg protein $(5 \mu \mathrm{g}$ protein/ml $)(\times)$, or both together ( $\square$ ) were added to native LDL at zero time. The results are expressed as the change in $\mathrm{A}_{234}$ and were confirmed by two other experiments.

Figure 5. The effect of the addition of a fatty acid hydroperoxide to native LDL on the antioxidant to pro-oxidant switch for dehydroascorbate. (A) Native LDL (50 $\mu$ g protein/ml) in 
PBS was incubated at $37^{\circ} \mathrm{C}$ with $\mathrm{CuSO}_{4}(5 \mu \mathrm{M}$ net) (O). Dehydroascorbate (DHA; $10 \mu \mathrm{M})$ was added to native LDL at zero time $(\bullet)$. The lipid hydroperoxide 13-HPODE was added to native LDL at zero time at concentrations of $10 \mathrm{nmol}(\mathbf{X}), 20 \mathrm{nmol}(\diamond)$ or $30 \mathrm{nmol} / \mathrm{mg}$ LDL protein $(\square)$. Lipid hydroperoxides were also added to native LDL in the presence of dehydroascorbic acid (10 $\mu \mathrm{M})$ at concentrations of $10 \mathrm{nmol}(\boldsymbol{\Delta}), 20 \mathrm{nmol}(\bullet)$ or $30 \mathrm{nmol} / \mathrm{mg}$ LDL protein $(\mathbf{\square})$. The results are expressed as the change in $\mathrm{A}_{234}$ and were confirmed by two other experiments. (B) Native $\mathrm{LDL}(50 \mu \mathrm{g}$ protein $/ \mathrm{ml})$ in $\mathrm{PBS}$ was incubated at $37^{\circ} \mathrm{C}$ with $\mathrm{CuSO}_{4}(5 \mu \mathrm{M}$ net $)$ in the presence of 13-HPODE (20 nmol/mg LDL protein), to induce the switch in the antioxidant to pro-oxidant activity of dehydroascorbate (duplicates shown by $\bigcirc$ and $\times$ ). Dehydroascorbate at a concentration of $10 \mu \mathrm{M}$ (duplicates shown by $\boldsymbol{\Delta}$ and $\square$ ), $30 \mu \mathrm{M}$ (duplicates shown by $\boldsymbol{+}$ and $\boldsymbol{*}$ ) or $100 \mu \mathrm{M}$ (duplicates shown by $\triangle$ and $\diamond$ ) was added at zero time. The results are expressed as the change in $\mathrm{A}_{234}$ and were confirmed by another experiment.

Figure 6. EPR spectra of DMPO radical adducts detected following the addition of $\mathrm{CuCl}_{2}$ to tert$\mathrm{BuOOH}$ in the presence of ascorbate or dehydroscorbate. Spectrum D is shown expanded 10-fold in the $y$-axis relative to the others.

Figure 7. Decay kinetics of the erythroascorbate (A) and ascorbate (B) radicals observed by EPR spectroscopy following the reaction of $25 \mathrm{mM}$ dehydroascorbate and $25 \mathrm{mM}$ ascorbate, respectively, with $2.5 \mathrm{mM} \mathrm{Cu}^{2+}$ under continuous-flow conditions (post-mixing concentrations). The insets in A and B show the spectra of the erythroascorbate and ascorbate radicals, respectively, and the measurements taken as peak heights. The reciprocal plot $(\mathrm{C})$ of the ascorbate data was used to convert peak heights to radical concentrations (see text for details).

Scheme 1. Summary of reactions proposed to be responsible for the behavior of dehydroascorbate (DHA) toward LDL undergoing oxidation catalyzed by $\mathrm{Cu}^{2+}$ ions. See text for details. 